\title{
Latex-fruit syndrome and degree of severity of natural rubber latex allergy: is there a link?
}

\author{
Elisabetta Calamelli, Valentina Piccinno, Arianna Giannetti, Giampaolo Ricci, Andrea Pession \\ From Food Allergy and Anaphylaxis Meeting 2011 \\ Venice, Italy. 17-19 February 2011
}

\section{Background}

Latex-fruit syndrome (LFS), defined as hypersensitivity to particular fresh fruits (Wagner S. E Breiteneder $H$. Bioch Soc Trans, 2002), has been described in $30-50 \%$ of pts affected from natural rubber latex (NRL) allergy and it is due to IgE Abs that cross-react with similar epitopes on phylogenetically related proteins. Objective: To estimate the prevalence of LFS in a group of NRL allergic children and adolescents and to evaluate a possible correlation with the severity degree of NRL allergy.

\section{Methods}

This retrospective study analyzed 22 pts $(17$ M, 5 F; mean age 15,2 yrs) referred to the Pediatric Allergology of University of Bologna from Jan. 1990 to Sept. 2010 with a history of IgE-mediated NRL allergy associated with a level of latex specific IgE (sIgE) $\geq 0.35 \mathrm{kU} / \mathrm{L}$ (ImmunoCAP 1000, Phadia; Sweden) and/or a positive response to Skin Prick Test (wheal $\geq 3 \mathrm{~mm}$ ) with latex extract (Lofarma, Milan; Italy). Levels of total and sIgE to grass pollen and to the main fruits implicated in LFS were analysed.

\section{Results}

The mean age at diagnosis of NRL allergy was 7,2 yrs (range 3-12). NRL allergic pts were divided in 2 groups, according to the severity of symptoms after latex contact. In group A were included 13 pts (59\%) with mild symptoms (contact urticaria); in group B the remaining 9 subjects $(41 \%)$ with moderate-severe symptoms (generalized urticaria w/wo angioedema and/or respiratory symptoms and/or anaphylaxis). Eight of the 22 subjects $(36,4 \%)$ reported symptoms from LFS to the following fruits or combination of its: kiwi (5), peach (2), chestnut (2), cherry (1), apple (1), melon (1). The prevalence of LFS

University of Bologna, Dipartimento di Pediatria, Bologna, Italy

Full list of author information is available at the end of the article was higher in group B than in group A (respectively 7/9, $78 \%$ vs. $1 / 13,8 \% ; \mathrm{p}<.005$, Chi-square test). No statistically differences in median values of total and SIgE were found between the 2 groups (Mann-Whitney U test).

\section{Conclusions}

Our study confirms a relevant prevalence of LFS (36,4\%) in patients with NLR, with kiwi, alone or in combination, as the main implicated fruit. Moreover, a significantly higher prevalence of LFS in subjects with more severe manifestations of NRL allergy was documented.

Published: 12 August 2011

doi:10.1186/2045-7022-1-S1-018

Cite this article as: Calamelli et al:: Latex-fruit syndrome and degree of severity of natural rubber latex allergy: is there a link? Clinical and Translational Allergy 2011 1(Suppl 1):O18.

\section{Submit your next manuscript to BioMed Central and take full advantage of: \\ - Convenient online submission \\ - Thorough peer review \\ - No space constraints or color figure charges \\ - Immediate publication on acceptance \\ - Inclusion in PubMed, CAS, Scopus and Google Scholar \\ - Research which is freely available for redistribution

